\title{
The Eruption of Mount Kelud and It's Impacts in Blitar 1919-1922
}

\author{
Ulin Nihayatul, , Agustinus Supriyono, Haryono Rinardi \\ Master Program of History, Faculty of Humanities, Diponegoro University \\ *Corresponding Author: ulin_nihay@yahoo.com
}

\begin{abstract}
This study is meant to deal with the aftermaths of Mount Kelud Eruption from 1919 to 1922 in the region of Blitar, which is focused on the effects of

Received:

2 April 2017

Accepted:

18 May 2017

Mount Kelud eruption on the economy and its impacts for the three years following the eruption. The aftermaths of Mount Kelud eruption of 1919 had caused many of the residents lose their livelihood, families and damages to the plantations in the region of Blitar. The damages affecting the plantations made the local economy in the region of Blitar drop. This economic slump certainly impeded the development progress in the Gemeente of Blitar, a Gemeente had been formed in the region of Blitar shortly before that. The extensive environmental devastation, inside the gemeente and the outer parts of the regency's regions forced the regional government of Blitar Regency to allocate aids funds to handle the casualties, make the repairs and constructions of the facilities in the region of Blitar.
\end{abstract}

Keywords: Eruption; Mount Kelud; Blitar.

\section{Introduction}

The great number of population with uneven distributions, disorderly spatial detail, the issues of deviating usage of natural resources, diverse tribes and tribal groups, religions, traditions, cultures, and the impacts of globalization and other complex social problems have existed in the country. This condition has consequently made Indonesian territories to become areas of potential disasters, both natural and manmade calamities. Some of these are, among other things, an earthquake, tsunami, flood, landslide, hurricane, forest fire and volcanic eruption.

Indonesia is known to be home of $\pm 30 \%$ of the world's active volcanoes. Based on the records of volcanic eruptions recorded in history, the Indonesian volcanoes may be classified into three types. Type A accounts for 79 volcanoes which have erupted since 1600. Type B represents 29 volcanoes which erupted before 1600, and Type C, amounting to 21 volcanoes composed of lapangasolfatara and fumarola volcanoes (Van Bemmelen, 1949:73). Based on the history of eruptions and combined with the physical characteristics, apex natural spans (bentang alam puncak), volcanic structure, and types of the eruptions, the active volcanoes situated in Indonesia may be classified into eight 
types, the Tambora 1815 type (caldera eruption), the Merapi type (lava dome crater), Agung type (open crater), the Papandayan type (collapsed craterwall), Batur type (post-caldera), Sangeangapi type(lava flow), and the Anak Krakatau type (under-sea volcano).

Mount Kelud is one of the most active volcanoes in Indonesia. Mount Kelud has erupted more than 30 times since 1000 AD. During the colonial period, Mount Kelud was recorded to have erupted many times, inter alia, in 1826, 1848, 1864, 1901 and 1919. During the Independent Era, Mount Kelud has erupted in 1951, 1966, and 1990 respectively. Therefore, this volcano is recorded to have actively erupted, with short periodical gaps (9-25 years) (Reksowirogo, 1979:282-283). Every eruption of Mount Kelud has been ended with the formation of a lava blockage in its lava vent. Mount Kelud is also grouped as a stratovolcano, a volcano typified by its massive and explosive characteristics.

One of Mount Kelud's largest eruptions took place in 1919. In the illustrating words (perspective) of the Dutch geologist, G.L.L. Kemmerling, the eruption spewed ashfall and hot clouds which was, and still is, called wedhus gembel (for resembling the shape of a sheep's fur (wedus gembel). What attracts attention from the 1919 eruption is that Mount Kelud not only gushed hot clouds but also spewed hot lava previously deposited under the crater. The volume of the hot lava was then estimated to reach \pm 40 cubic meters. And worse still, the eruption was accompanied with heavy rain resulting in the subsequent cold lava flow. The rain made the volume of water in the crater increase, and the cold lave flow brought with it different materials (objects), such as sand, gravels and stones flowing down along with the water from the crater. The flow devastated residential homes of the local residents. As a result, massive damages to the existing infrastructure that the lava passed through ensued.

The hot lava spewed out of Mount Kelud eruption in 1919 was reported to have destroyed the areas of the plantations located on the slopes of Mount Kelud, Sumber Petung and Margomulyo plantations (Kemmerling, 1921:2-3). The hot lava spewed out carried with it other volcanic materials and mud which flowed down at a high speed and reached a distance of as far as $38 \mathrm{~km}$ from the tip of mount Kelud. The hot lava, which was followed by the cold lava, flowed through River (Kali) Lekso, River (Kali) Putih and finally entered River Brantas and had swept down all the areas where the flow had passed through in the region of Blitar. The lava flowing through River (Kali) Badak had caused major damages and claimed a number of casualties on its way, in the regions of Blitar and Srengat. The lava flow carried a lot of stones, sand, wooden remnants and other materials. These materials made the irrigation and water ways and bridges blocked. The subsequent results were the overflows of lava sweeping and inundating the regions and villages located in the surrounding areas. The day after the eruption, May 19 th 1919 , the lava flow begun to reach the government center in the region of Blitar. This condition forced the Dutch officials to evacuate and save themselves to higher locations. In relation to this situation, the train was prepared at Blitar train station to evacuate the refugees. Blitar train station became the assembly 
point for people who were then evacuating themselves. However, the station was not free from the flow of the cold lava, as a result, not all of the residents were evacuated.

One of the main causes that made Mount Kelud Eruption of 1919 so devastating with catastrophic and fatal disasters was the flow of hot lava and subsequently followed with the cold lave streams, flowing down in great quantities and sweeping through the residents' homes in the villages located on the slopes of Mount Kelud because the embankments located on the rivers were unable to accommodate the volume of the oozed out lava. The Eruption of Mount Kelud in 1919 was so disastrous that the ash fall and quakes were suffered by people living in different regions in Java, such as Priangan (West Java), Banyumas, Semarang, Yogyakarta, Madiun, Rembang, Surabaya, Pasuruan and other places (Kemmerling, 1921:4). Based on the report from Junghuhn, the sound of the eruption heard in Banjarmasin on the island of Kalimantan.

Apart from the heavy casualty, claiming \pm 5.000 the lives of people, the 1919 Mount Kelud eruption also killed many of the local resident's cattle and serious environmental damages in the region of Blitar, including the infrastructure owned by the government of Blitar, the residents' agriculture and privately owned plantations. Based on the historic background descriptions of Mount Kelud eruptions, the topics to be discussed in this thesis are as follows: 1. How Mount Kelud Eruption in 1919 influenced the economic and environmental conditions in Blitar? 2. What factors made the eruption claim so many lives of people, cattle, and the damages to the residents' crops? 3. What did the Government do to help the people inflicted by the calamity of the eruption of Mount Kelud in 1919?

\section{Method}

A number of colonial archive sources, classified as both primary and secondary sources, which are relevant and bearing evidencing properties and historical facts have been used in this study, which include, among other things: memorie van Overgave, Staatsblad van Nederlandsch-Indie. Apart from that, classified as secondary sources used include, among other things: Nota in zake de Maatregelen Getroffen op Verkeers Hygienisch en Economisch Gebied in door de Kloeteruptie van 19 op 20 Mei 1919, De KloetrGas Eruptions of the Kelut in 1919 Wedusgembels of the Kelut 1919 disadvantageous Effect of the ash rain of Mount Kelut in 1919 amp van 20 Mei 1919, The Outburst of the Mount Kelut in the night of May 19 th to 20 th 1919, Encyclopaedie van Nederlandsch-Indie. These sources were acquired from different places, primarily from Republic of Indonesia's National Archive or Arsip Nasional Republik Indonesia (ANRI), Indonesian National Library or Perpustakaan Nasional Republik Indonesia (PNRI), Library of the Directorate of Volcanology and a number of other libraries. The collected data were then analyzed through the historical method and supported with the use of conceptual frame. As a work of historiography this study is confined within the spatial scope, which includes the region of Blitar and the temporal scope covering the 1919-1923 period or the era when this eruption Mount Kelud took place and then unrecovered economy. 


\section{Results and Discussion}

\section{Geographic and Demographic Conditions of Blitar}

Blitar is located in the Province of East Java. Geographically, it is located at $11125^{\prime}-112$ 20' East Longitude and 7 57-8 9'51 South Latitude, and is located southwest to the capital city of East Java Province at a distance of $\pm 160 \mathrm{~km}$. The region of Blitar is \pm 160 km away from Mount Kelud (Kerchman, 1905-1930:367-370). Because the western border of Blitar is near Kediri, when Mount Kelud erupts the lava flow usually passes this area. This geographical condition is caused by the fact that a river originating from Mount Kelud. The eruptions of Mount Kelud may cause instant damages but in the long run the volcanic ash will make the soil in Blitar very fertile. A number of rivers flow from Mount Kelud through the region of Blitar Regency, including : (1) River Lekso; (2) River Putih; (3) River Lahar Badak (now Bendungan Badak); (4) River Temas (passing through Udanawu); (5) River Kali Kuning and River Lahar Blitar (Dingemans, 1923:3).

In 1905 the population was \pm 342.000 , in the Regency of Blitar of that time, the Chinese community accounted for \pm 2200 and Europeans \pm 900 (Bleeker, 1844:315). The majority of the people then living in the region of Blitar Regency were farmers or plantation workers. The condition of the soil in the Gemeente of Blitar was not different from that of other areas in Blitar Regency, mostly consisting of regusol and litusol. Like other areas of Blitar Regency, the Gemeente of Blitar was located inside the region of Blitar Regency, some rivers also flowed through the Gemeente of Blitar, such as River Cari, River Urung-urung, River Tugu, and River Gedog. The population of the Gemeente of Blitar in 1905 was comprised of $\pm 24,371$ indigenous people $(87.52 \%), \pm 674$ $(2.42 \%)$ Europeans, $\pm 2,746$ Chinese $(9.86 \%)$ and other ethnic groups accounting for \pm $56(0.20 \%)$, thereby totaling \pm 27.846 (Grijns, 1979:33). As a seat of the government center, the gemeente and regency also housed a number of offices of the plantations and other companies located in the Gemeente of Blitar. This function was facilitated with the available infrastructure such as streets, bridges, train station, post office and other public facilities. This flat and easily accessible plain and inter-relating to other areas made the Gemeente Blitar heterogeneously populated, apart from its role as a government, this region was a strategic location for controlling the activities in the plantations and companies owned by the Europeans.

\section{Eruption of Mount Kelud in 1919}

Mount Kelud is a volcano with a height of \pm 1.731 above sea level, it is located $7^{0} 56^{\prime}$ South Latitude and $112^{\circ} 18^{\prime}$ point five East Longitude. Geographically, Mount Kelud is located on the borders of Kediri, Blitar, and Malang Regencies. The formation of Mount Kelud was the result of the subduction of Indo-Australia continental plate and Eurasia continental plate. Mount Kelud bears the typical characteristics of a stratovolcano with a crater lake and explosive eruptions. Mount Kelud, which bears a stratovolcano characteristic, or a conical in the bottom with its crater lake, when 
erupting this mountain will be able to spew a great quantity of lava, accompanied by the flow of hot water and from its crater lake.

One of the greatest eruptions of Mount Kelud occurred on May 19th 1919 . This eruption has been considered to be the biggest in the twentieth century, and the crater of this mountain became wider. This subsequently raised the volume of the water from it previously had been, especially in the rainy season. The direct effects of the eruption of Mount Kelud was the great environmental damages in the region of Blitar, agricultural fields and crops, plantation, houses of the people and loss of lives. These damages were caused by the volcanic materials, consisting of ashfall, gravels, and water from the crater spewed out during the eruption. These indirectly reduced the harvests in the following years. The eruption took place the night of the $19^{\text {th }}$ was still felt on May 20 $0^{\text {th }}, 1919$. The morning suddenly became dark, the sun was not seen, with the rain of water, gravels and ash, and people became scared, the air heavy and dusty which made breathing difficult (Kemmerling, 1946). People were running here and there, trying to save their lives and belongings and cattle that could still be saved. The areas where the lava flow passed were, among others, Sanankulon, Nglegok, Srengat, Ponggok, Udanawu, Gandosari, and Talon (Koning, 1919:94). The water flow carried a great quantity of garbage which bloced waterways and irrigation ditches and bridges, so the water overflowed and inundated the surrounding villages. The great casualties consisted of humans, cattle, damaged plantation crops, houses and the facilities having been built by the government. Mount Kelud spewed \pm 40 cubic meters of water. The water was mixed with boulders and mud and flowed up to 38 kilometers away, sweeping large areas in the region of Blitar.

Other sources mention that the water in the crater lake was starting to boil on May 19th, 1919 and the lake spilled out approximately 40 million cubic meters of water and the lava flowed over the villages located on the slope of the mountain. ${ }^{12}$ This hot water flowed down and hit the Badak Embankments (Tanggul Badak), destroying everything on its route. Five thousand people died instantly. Bodies with severe burns were reported carried down by the lava. This scary situation was worsened by the fact that Mount Kelud was at the same time spewing hot clouds (Harderwijk).

The lava was intensely dangerous for the people living on the slopes on a volcano. Apart from the lava, the eruption of the mountain was also accompanied by ash falls blown airborne during the eruption. The ash was blown away by the wind to distances thousands of kilometers away. The thickness of the ash in different areas varied, as the direction of the wind became one of the aspects determining the impacts of Mount Kelud's eruption in each different area. The eruption of Mount Kelud was not only perceivable in the region of Blitar but also suffered by most regions on the island of Java. Some reports of the indirect effects of the eruption of Mount Kelud, and in particular the ash falls, are s follows: 1). Pasuruan, 2). Surabaya 3). Madiun, 4). Yogyakarta, 5). Rembang, 6). Semarang, 7). Banyumas, and 8). Priangan. The explosion Mount Kelud was heard Bandung, Banjarmasin and other parts of Kalimantan (Kemmerling, 1921: E. 19-4). 


\section{Socio-economic Impacts of the 1919 Mount Kelud's Eruption}

Damages to the infrastructure in Blitar

The infrastructure of a town or city or a region come in the form of streets, bridges, waterways or irrigation and so forth. The so many infrastructure buildings in Blitar Regency damaged by the eruption Mount Kelud in 1919 included streets, bridges, buildings and houses (Verslag Burgerlijke Openbare Werken Nederlands, 1919-1920:176177, Decentralitatie Verslag, 1919-1920: 144, Dingemas, 1923:42-43). The damaged streets and bridges made communication and travels to and from other towns difficult and the government affairs impeded.

These damaged infrastructure facilities took a long time to restore. This caused declines in the economy of Blitar. The access to and from other towns was delayed, making the plantation yields and agricultural harvests impossible to be distributed to the customers. Moreover the products of the plantation and agriculture crops produced by the farmers and plantations in Blitars could not processed to give them added values, because the milling or processing facilities were located in Blitar, while the plantation and agriculture areas were located in rural areas. The eruption of Mount Kelud in 1919 not only caused damages to the public infrastructure but also destroyed a number of facilities and amenities in Blitar. The damages happened to:

1) People's houses and government buildings

The damages to people's houses were associated with the location of the houses which were on the river bank or places near the rivers where the lava from the eruption of Mount Kelud flowed. The damaged houses, both in the region of the regency and in the gemeente of Blitar itself totaled $\pm 35,758$, with Sanankulon Onder-district suffering the most, with 8.544 houses being destroyed, among the 11 under-districts and the number of damaged houses reached \pm 8.968 , the highest number being in the under-district of Blitar. In addition to the damaged houses, a number of public buildings and facilities built by the government were also damaged. These included the prison, post office and market.

2) Streets

Streets are a part of transportation facilities that relate one area to another. The 1919 Mount Kelud Eruption made the streets in the region of Blitar damaged, including the railway relating Blitar to other towns and cities (Verslag Burgerlijke Openbare Werken Nederlands, 1919-1920: 167-177).

3) Bridges

The region of Blitar had many bridges because a lot of rivers pass through this region. The eruption of Mount Kelud damaged most of the bridges. The damaged bridges were Djagalan, Lekso, Glondong, Jembatan Kademangan, Blaroe, Bendo, Nglongsor, Binangun, Loading, Sawentar, Semoet, Konto, Djatilengger, and Pakunden bridges (Dingemas, 1923:42-43).

\section{Damages to agriculture and cattle}

The eruption of Mount Kelud in 1919 damaged the ambient environment. The eruption also claimed a number of human casualties, \pm 5235 people were reported 
dead. In addition to human casualties, the eruption also destroyed \pm 103 villages in 10 under-districts in the region of Blitar (Dingemas, 1923:11). Other damages happened to agriculture, plantations and cattle. The catastrophe claiming human lives was caused by two factors. First, the ash and gravel or stone rains occurred during the eruption. After the hot clouds, the ash and stone rain followed, causing damages to crops and plantations in the short term. Second, the cold lava flows destroyed and flooded the villages located in the surrounding areas. Apart from the human lives, cattle owned by the local residents were killed by the eruption of 1919 Mount Kelud eruption. These included cows, horses and goats.

Table 1. Number of Cattle killed in 1919 Eruption

\begin{tabular}{lrrrr}
\hline \multicolumn{1}{c}{ Under-district } & Buffaloes & Cows & Horses & Goats \\
\hline Blitar & 173 & 452 & 274 & 34 \\
Sanankulon & 1,039 & 2,079 & 155 & 18 \\
Nglegok & 524 & 1,231 & 32 & 123 \\
Srengat & 1,617 & 4,018 & 141 & 205 \\
Ponggok & 1,422 & 1,923 & 101 & 580 \\
Udanawu & 2.287 & 2.922 & 188 & 475 \\
Gandosari & 110 & 251 & 4 & 111 \\
Talon & 272 & 376 & 5 & 25 \\
\hline Total & 7,444 & 13,252 & 900 & 1,571 \\
\hline
\end{tabular}

Source: Koning, 1919.

The ashfall from the eruption of the volcano put weights on the leaves which in turn made the tree collapse, suffer from suffocation, lack of oxygen and finally die. This destruction did not only attack rice, corn and non-rice crops and even big trees in the forest and a lot bamboos collapsed for being unable to withstand the weight. The damages inflicting various crops resulted in the decreased agricultural harvests in the following (planting) periods (Dingemas, 1923:24). In general, three years after the eruption the harvests in the district of Blitar still showed a decline. This decline occurred with corn, cassava, and tobacco. The harvest decline was associated with the damaged rice fields (sawah), irrigation system, and other facilities destroyed by the flow of cold lava during the 1919 Mount Kelud eruption. A different condition happened to some other types of crops, such as tubers, peanuts and soybeans which showed an increase after the eruption of Mount Kelud. The increase was probably caused by the fact these crops do not need much water, as the rice paddy does. Another factor, these three types of crops are highly adaptable to the soil then covered by volcanic ash layers. The other factor was the humans (farmers) themselves.

The rice harvest in Srengat District in 1922 showed a decrease by 3,730 pikul (a unit of measurement equal 61.76 kilograms) or 30\% decrease compared to that of 1918 (Dingemas, 1923:24). The district of Srengat suffered the greatest decline because this area was struck by the lava flow. A contrast occurred in the region of the District Blitar, after the eruption the rice harvest increased by 19,615 pikul. The agricultural areas in 
the District of Blitar were not affected by what happened in Srengat. Another factor that accounted for such increase was that the volcanic ash indirectly added the fertility on these agricultural areas. During the eruption the wind blew southward.

\section{Government efforts to overcome the aftermaths of Mount Kelud eruption}

1) Government's steps to handle people, agriculture and cattle

The Gemeente of Blitar and the Regency of Blitar had done their best to overcome or at least to lessen the suffering then inflicting the local residents. A lot of people died and were injured in the region of the following under-districts: Blitar, Nglegok, Srengat, Ponggok, Udanawu, Gandosari, and Talon. Many of the hospital in Blitar were unable to accommodate the victims, so the Government built emergency hospitals. Doctors, paramedics, medical equipment and supplies, medicine and ambulances from other areas outside Blitar were also called in (Koning, 1919:141). They were assigned to help the victims of the eruption of Mount Kelud in 1919. TO help the victims of 1919 Mount Kelud Eruption, some emergency medical facilities were built in several locations, including:

a) Talon, an emergency hospital was built on May 21st, 1919

b) Mangunan, an emergency clinic was built from May 22 $2^{\text {nd }}, 1919$ to May $26^{\text {th }}, 1919$

c) Bendo, an emergency clinic was built on May $26^{\text {th }}, 1919$

d) Ponggok, an emergency clinic was built on May $26^{\text {th }}, 1919$

e) Srengat, an emergency clinic was built from May $24^{\text {th }}, 1919$ to May $28^{\text {th }}, 1919$

f) Nglegok, an emergency clinic was built on May $26^{\text {th }}, 1919$

The medical treatments for the 1919 Mount Kelud casualties were also done in the existing hospitals, among others:

a) H. V. A. Hospital in Toeloengredjo,

b) Hospital in Kediri,

c) Government and private hospitals in Blitar,

d) Health Clinic in Kediri,

e) Health Clinic in Tulung Agung,

f) Health Clinic in Pare.

The government spent $\pm f 51,249$ on medicine, funerals and clothes for this Mount Kelud Eruption. The government further gave compensations amounting \pm $f 59,6960$ for the damages suffered by the people affected by the 919 Mount Kelud Eruption, given to the Europeans, Japanese, Indians, Chinese, Native Residents and Civilians or the villages' administrators (Dingemas, 1923:11).

In response to the Eruption of Mount Kelud, the then government of Blitar showed their concern to the affected people. To assist people, especially those living in the villages, to be able to cultivate their agricultural land, the government provided $\pm f 41,418$ to buy agricultural tools and equipment, sewing machines, purchase of seeds to be planted, cattle, and to restore the forest in Bronkos. These efforts were made in order recover the economy and daily life of the people in Blitar as soon as possible. 
2) Government's effort to repair the infrastructure

The extensive damages to the infrastructure in the region of Blitar farced the government to respond. The Gementeraad decided to repair the streets on the funds acquired from the central Government. The destruction also caused a number of bridges to be damaged. The Government immediately repair these damaged bridges so that the transportation in Blitar might recover. The Government spent $f$. 17,088 on the repairs of the streets and bridges. The funds were acquired from the government budget, government loans and donations from different parties and resources. The damaged bridges then to be repaired include, inter alia: a). Lekso Bridge for the town of Wlingi, b). Glondong Bridge for Blitar, c). Kademangan Boro Bridge for Blitar, d). Blaroe, e). Bendo, f). Nglongsor, g). Binangoen, h). Sangoet, i). Pakoenden, j). Loding, k). Sawentar, 1). Ganggangan, m). Semoet, n). Konto, o). Djatilengger bridges (Dingemas, 1923:42-43). The repairs to theses bridges took quite a long time. The Government spent a lot of funds to restore the condition destroyed by the 1919 Eruption of Mount Kelud, the funds spent amounting to $\pm f$ 118,6740 .

The funds acquired to make the repairs to the infrastructure and facilities as well as the compensations for the victims of Mount Kelud's eruption were enormous but on the contrast the Government's finance was limited. The repairs to the damaged infrastructure and facilities caused by Mount Kelud eruption were made on the scale-of-priority basis. The fund resources were not only from the Government but also from the fundraising done by the people. In this case, the people spontaneously formed disaster- awareness associations or committees for Mount Kelud Eruption victims. The committees came from places outside Blitar, such as Surabaya, Malang and Yogyakarta (Kawan Kita, 26 Mei 1919:171). The fund aids were acquired from spontaneous night fairs, donations from cigarette factories, rice millings and other donators. The aids were not only in the form of cash but also in the form of clothes, blankets, food, medicine, and sheets of fabric. Apart from the direct aids to the victims of the disaster, the government also began to build tunnels at the feet of Mount Kelud, as an anticipation for the following eruptions of Mount Kelud.

The Dutch Colonial Government built seven tunnels which functioned as buffers of the cold lava at the feet of Muont Kelud. The construction of these tunnels was started in 1923 and completed in 1926. These tunnels would reduce the debits of the cold lava from the crater of Mount Kelud, so that the quantity of the cold lava which might originally pass the residential homes of the people would be greatly reduced. In this way, the casualty suffering from the erution of Mount Kelud may be minimized.

\section{Conclusion}

Indonesia is a highly prone to natural disasters. Indonesia has the most active volcanoes on earth. However, both Indonesian Government and people do not have sufficient sense of awareness toward natural disasters. This was/is proven with the 
eruption of Mount Kelud which happened in the night of May 19 ${ }^{\text {th }}, 1919$. The region of Blitar was seriously affected by the volcanic eruption, in which many of the facilities and infrastructure were badly damaged. Thise condition covered all the areas located in the regency and Gemeente of Blitar. The destruction was caused by the characteristics of Mount Kelud eruptions, the explosive eruption (explosion) where volcanic materials were spewed out of the inner part of the mountain and fell onto these areas in Blitar, which was followed by the flow of hot lava mixed with other volcanic materials, passing through the residential homes of the people living in the region of Blitar, without any previous predicted warnings.

The eruption of Mount Kelud in 1919 shows that Indonesian people, and even the colonial government of that time, do not and did not have high awareness toward natural disasters, and in particular with regard to volcanic eruptions. This condition can be seen in the limited infrastructure development and construction located around Mount Kelud. As a result, a great number of the lives and material losses were unavoidable. The other indicator is the many residential locations situated on the slopes or at the foot of Mount Kelud, which are certainly disaster-prone. People prefer to live in fertile areas so that they may easily cultivate the land for agriculture. This preference has made areas close to rivers and having fertile soil layers their choice. This has also happened on the slope and foot of Mount Kelud. These people do not realize the potential dangers when Mount Kelud may erupt at any time. Another indicator is that there is no anticipation and obvious plans from the Government if Mount Kelud erupts at any time. The disaster of Mount Kelud's eruption in 1919 has shown an interesting fact. The Colonial Government and people both had the high responsibility and social spirits. The government responded and quickly evacuated the victims of the eruption. The Government even provided the victims with aids, from material things to medical assistance. In addition, people also took the necessary steps to help the victims of the disaster caused by the eruption of Mount Kelud. It is shown in the so many volunteers who came from places outside Blitar, even from Singapore. These volunteers came to assist the Government to help or save the people of Blitar who were becoming the victims of the eruption of Mount Kelud.

Apart from directly assisting the victims of the eruption of mount Kelud, the Colonial Government also took steps to reduce the number of casualties. In anticipation to another eruption of Mount Kelud if the volcano erupts again, the colonial government built tunnels in the foot of Mount Kelud in 1923. These tunnels serve as the buffers of the flowing lava and reduce the volume of the water flowing down from the crater lake when cold lave flows down and passes the residents' homes at the foot of Mount Kelud.

\section{References}

Bleeker, Pieter, (1844). Bleekers Papers, 1844-1867, Volume 3.

Decentralitatie Verslag, 1919 - 1920.

Dingemans, L.F. (1923). Nota in Zake De Maatregelen Getrofeen Op Verkeers, Hygienisch, En Economisch Gebied In De Kloeteruptie van 19 op 20 Mei 1919. Kediri. 
Grijns, C.D. (1979). A La Recherche du 'Malayu Betawi' ou Parler Malais de Batavia, Archipel, 17:135-136.

Harderwijk,Vulkaanrampen in Ned. Oost-Indië, dalam http://www.quickiwiki. com/nl/Kelud, retrieved 10 April 2015.

Kawan Kita, 26 Mei 1919.

Kemmerling, G.L.L. (1921). Amount of Ejected Ash and Pumice of the Kelud Eruption in 1919 E. 19. Bandung: Perpustakaan Direktorat Vulkanologi.

(1921). Gas Eruptions of the Kelut In 1919 Wedusgembels of the Kelut 1919

Disadvantageous Effect of the Ash Rain of Gunung Kelut in 1919 E. 19-5. Bandung:

Perpustakaan Direktorat Vulkanologi.

(1946). Gas Eruptions of the Kelut in 1919 Wedusgembels of the Kelut 1919

Disadvantageous Effect of the Ash Rain of Gunung Kelut in 1919. Bandung: Perpustakaan Direktorat Vulkanologi.

Kerchman, F.W.M. (1905-1930). 25 Jaren Decentralisatie in Nederlandsch Indie. Semarang: Uitgegeven Vereeniging voor Locale Belangen.

Koning, J. “De Kloetramp van 20 Mei 1919”, Soerabaiasch Handelsblad, July 1919.

Grijns, Mies (1979). De Koloniale Stad in Indonesie. Leiden: Doctoral Scriptie.

Reksowirogo, L.D. (1979). Data Dasar Gunung Api Indonesia. Bandung: Direktorat Vulkanologi.

Van Bemmelen, R.W. (1949). The Geology of Indonesia. The Hague: Martinus Nijhoff.

Verslag Burgerlijke Openbare Werken Nederlandsch-Indie over Jaren 1919 en 1920 (1925). Weltevreden : Landsdrukkerij. 